\title{
Influence of thyroidectomy on thyroxine metabolism and turnover rate in rats
}

\author{
Hidenori Nagao' ${ }^{1}$, Tetsuya Imazu ${ }^{1}$, Hiroyuki Hayashi ${ }^{2}$, Kenjo Takahashi ${ }^{\mathbf{3}}$ and Kouichi Minato ${ }^{\mathbf{1}}$ \\ ${ }^{1}$ Pharmacokinetics Research Department of ASKA Pharmaceutical Co., Ltd, ${ }^{2}$ Synthetic Research Department of ASKA Pharmaceutical Co., Ltd \\ and ${ }^{3}$ ASKA Pharma Medical Co., Ltd, 5-36-1, Shimosakunobe, Takatsu-ku, Kawasaki 213-8522, Japan \\ (Correspondence should be addressed to K Minato; Email: minato-k@aska-pharma.co.jp)
}

\begin{abstract}
Little is known about the kinetics and metabolism of thyroid hormones in the hypothyroid state. To investigate these factors, we developed a reliable method for measurement of serum thyroxine $\left(\mathrm{T}_{4}\right)$, triiodothyronine $\left(\mathrm{T}_{3}\right)$, reverse- $\mathrm{T}_{3} \quad\left(\mathrm{rT}_{3}\right)$ and stable isotope-labeled $\mathrm{T}_{4}$ $\left(\left[{ }^{13} \mathrm{C}_{9}\right] \mathrm{T}_{4}\right)$, using online solid-phase extraction liquid chromatography-mass spectrometry/mass spectrometry (online SPE LC-MS/MS). We measured supply and turnover rates of $\mathrm{T}_{4}$ in thyroidectomized $(\mathrm{Tx})$ rats using $\left[{ }^{13} \mathrm{C}_{9}\right] \mathrm{T}_{4}$ as a tracer. In rats, serum $\mathrm{T}_{4}, \mathrm{~T}_{3}$ and $\mathrm{rT}_{3}$ were decreased but not completely ablated after surgical $\mathrm{Tx}$. Endogenous $\mathrm{T}_{4}$ and $\mathrm{T}_{3}$ levels in $\mathrm{Tx}$ rats were maintained at a constant low level throughout the experimental period. $\left[{ }^{13} \mathrm{C}_{9}\right] \mathrm{T}_{4}$ levels declined with a half-life of $\sim 1 \cdot 2$ days after it was administered to Tx rats intravenously. These findings
\end{abstract}

strongly suggest that serum $\mathrm{T}_{4}$ levels in $\mathrm{Tx}$ rats are maintained by $\mathrm{T}_{4}$ supplied by extra-thyroidal tissues (e.g. secretion of extra-thyroidal storage, enhancement of enterohepatic recirculation, and production in extra-thyroidal tissues). Moreover, the turnover rate of $\mathrm{T}_{4}$ in $\mathrm{Tx}$ rats was approximately twofold lower than in controls. This finding suggests that degradation of serum $T_{4}$ is repressed by $T x$. In conclusion, serum $T_{4}$ is maintained at a constant low level by $\mathrm{T}_{4}$ supply from extra-thyroidal tissues and repression of $\mathrm{T}_{4}$ degradation in Tx rats. The powerful online SPE LC-MS/MS tool can be used to investigate thyroid hormones kinetics and metabolism, and thus has the potential to be used as a diagnostic tool and to investigate the pathogenesis of thyroid disease.

Journal of Endocrinology (2011) 210, 117-123

\section{Introduction}

Thyroxine $\left(\mathrm{T}_{4}\right)$ is the main secretory product of thyroid follicular epithelial cells but has low biological activity. $\mathrm{T}_{4}$ is converted to the more active triiodothyronine $\left(T_{3}\right)$. Approximately $80 \%$ of the $\mathrm{T}_{3}$ produced daily is formed by removal of one iodine atom from the outer ring of $\mathrm{T}_{4}$ (outer-ring deiodination) in tissues outside the thyroid gland, such as the liver, kidney, muscle, and nervous system. The deiodination reaction is catalyzed by deiodinase enzymes. Two deiodinases, type 1 and type 2, catalyze the conversion of $T_{4}$ to $T_{3}$. Type 3 deiodinase catalyzes the conversion of $\mathrm{T}_{4}$ to reverse $\mathrm{T}_{3}\left(\mathrm{rT}_{3}\right)$ and of $\mathrm{T}_{3}$ to $3,3^{\prime}$-diiodothyronine (inner-ring deiodination) (Gereben et al. 2008); neither $\mathrm{rT}_{3}$ nor 3,3'-diiodothyronine has biological activity (Bianco et al. 2002). In addition to deiodination, $\mathrm{T}_{4}$ can be metabolized to its glucuronide forms by UDP-glucuronosyltransferases (UGTs). $\mathrm{T}_{4}$ glucuronide is readily excreted in bile and is subsequently hydrolyzed by $\beta$-glucuronidases in the intestine, and may affect the enterohepatic circulation of $\mathrm{T}_{4}$ (Visser 1994). It has been reported that UGT1A1 in the liver, UGT1A8 and
UGT1A10 in the intestine, and UGT1A7, UGT1A9, and UGT1A10 in the kidney mainly contribute to the $\mathrm{T}_{4}$ glucuronidation activity in humans (Yamanaka et al. 2007). The change of these activities via inhibition and induction by administered drugs (Ohnhaus \& Studer 1983, Isojarvi et al. 1992, Kiang et al. 2005) as well as genetic polymorphisms (Miners et al. 2002) may be a causal factor of interindividual differences in serum $\mathrm{T}_{4}$ level.

Evans et al. (1960) reported that thyroidectomized (Tx) rats, whose growth had plateaued, could be made to grow again with a daily injection of large doses of inorganic iodide (3-5 $\mathrm{mg} /$ day). It has been subsequently shown that daily administration of $5 \mathrm{mg}$ iodide to $\mathrm{Tx}$ rats partially restores their heart rate, metabolic rate, gonad and adrenal size and function, and pituitary acidophils (Evans et al. 1966). There are two potential mechanisms for this phenomenon: supply of thyroid hormones by extra-thyroidal tissues and repression of thyroid hormone degradation. Previously, $\mathrm{T}_{3}$ generation from $T_{4}$ using radiolabeled $T_{4}$ and $T_{3}$ has been reported in detail (Silva \& Matthews 1984a,b, Silva et al. 1984). However, little is known about the kinetics and metabolism of $\mathrm{T}_{4}$ in the hypothyroid state. 
A<smiles>[2H]c1c(I)c(Oc2cc(I)c(O)c(I)c2)c(I)c([2H])c1C([2H])(N)C(=O)O</smiles><smiles>NC(Cc1cc(I)c(Oc2ccc(O)c(I)c2)c(I)c1)C(=O)O</smiles>

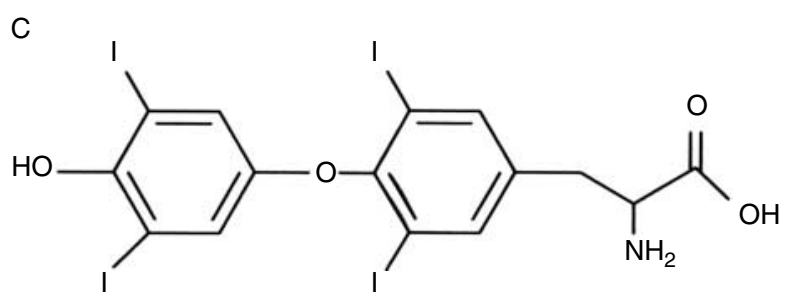

Figure 1 Chemical structures of $\left[{ }^{5} \mathrm{H}_{2}\right] \mathrm{T}_{4}(\mathrm{~A}), \mathrm{T}_{3}(\mathrm{~B})$, and $\mathrm{T}_{4}(\mathrm{C})$. $\mathrm{T}_{4}$, thyroxine; $\mathrm{T}_{3}$, triiodothyronine.

Although a sensitive and widely used immunoassay-based method exists for measuring serum thyroid hormones, there was a need for improved methods to investigate thyroid hormones kinetics and metabolism. Liquid chromatographymass spectrometry/mass spectrometry (LC-MS/MS) is capable of simultaneously and accurately detecting specific chemicals in various specimens. One of the unique advantages of this method, which uses a stable isotope-labeled compound as a tracer, is that an endogenous compound and its exogenously administered labeled analog can be measured separately using LC-MS/MS (Lin et al. 2010) or GC-MS/MS (Kasuya et al. 2005). Mass spectrometry of serum samples allows safe and precise in vivo measurement using stable isotopes, and such technology has contributed to a better understanding of metabolic diseases such as diabetes mellitus (Blaak et al. 2000, Hankard et al. 2000). Stable isotope-labeled tracers are commonly used to quantify the turnover rates of various metabolic intermediates and can provide information about physiological regulation. We have synthesized labeled $\mathrm{T}_{4}$ by region-selective labeling with carbon 13 . The biological tracer was $T_{4}$ with inner ring substitution with nine stable isotopes $\left(\left[{ }^{13} \mathrm{C}_{9}\right] \mathrm{T}_{4}\right)$. Quantification methods for endogenous and exogenous (stable isotope-labeled) thyroid hormones in animal serum using online solid-phase extraction (SPE) LC-MS/MS were developed using $\left[{ }^{2} \mathrm{H}_{5}\right] \mathrm{T}_{4}$ as an internal standard. After i.v. administration of $\left[{ }^{13} \mathrm{C}_{9}\right] \mathrm{T}_{4}$ to $\mathrm{Tx}$ and control rats, serum samples containing endogenous and exogenous (labeled) thyroid hormones were analyzed using the double isotope dilution method. We investigated supply and turnover rates of $\mathrm{T}_{4}$ in $\mathrm{Tx}$ and control rats by the stable isotope tracer method. The present study is the first to use stable isotope tracer injection in $\mathrm{Tx}$ rats.

The great potential of this technology can be extended to the use of $\mathrm{T}_{4}$ labeled with ${ }^{13} \mathrm{C}$ as a diagnostic tool for investigating pathogenesis of thyroid disease. The objectives of this study were to examine the kinetics and metabolism of $\mathrm{T}_{4}$ in the hypothyroid state using $\mathrm{Tx}$ rats.

\section{Materials and Methods}

\section{Chemicals}

L-T 4 - $\left[\right.$ L-tyrosine- $\left.{ }^{2} \mathrm{H}_{5}\right] \mathrm{HCl}$ (Fig. 1) was purchased from IsoSciences, LLC (King of Prussia, PA, USA). $\mathrm{T}_{4}, \mathrm{~T}_{3}$ (Fig. 1), and $\mathrm{rT}_{3}$ were purchased from Sigma-Aldrich Co. All other chemicals and reagents were of the highest analytical grade commercially available.<smiles>N[C@@H](Cc1ccc(O)cc1)C(=O)O</smiles>

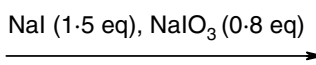

$15 \% \mathrm{AcOH}, 45 \mathrm{~min}, 45^{\circ} \mathrm{C}$<smiles>N[C@@H](CI1C=[IH](I)C(O)=[IH](I)C1)C(=O)O</smiles>

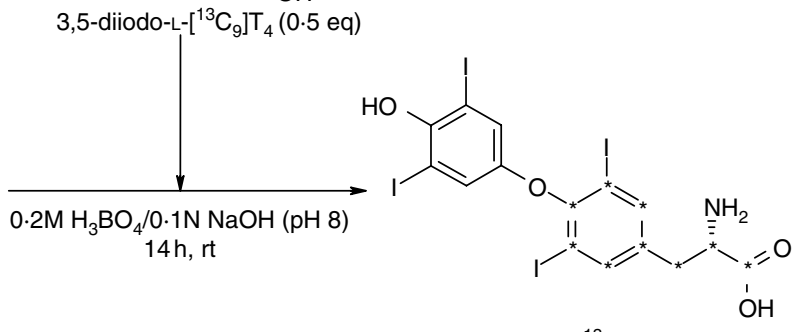

$\left[{ }^{13} \mathrm{C}_{9}\right] \mathrm{T}_{4}$

Figure 2 Chemical synthesis routes for $\left[{ }^{13} \mathrm{C}_{9}\right] \mathrm{T}_{4}$. rt, room temperature; asterisk denotes ${ }^{13} \mathrm{C}$. 
Table 1 Liquid chromatography (LC) conditions used for the online solid-phase extraction LC-mass spectrometry (MS)/MS analysis

\section{Mobile phase}

\begin{tabular}{|c|c|c|c|c|c|}
\hline \multirow[b]{2}{*}{ Time (min) } & \multirow[b]{2}{*}{ Flow rate $(\mathrm{ml} / \mathrm{min})$} & \multirow{2}{*}{$\begin{array}{l}\text { FCV-12AH valve } \\
\text { position }\end{array}$} & \multicolumn{2}{|l|}{ Pump A } & \multirow{2}{*}{$\begin{array}{l}\text { Pump B } \\
\text { B (\%) }\end{array}$} \\
\hline & & & A-1 (\%) & A-2 (\%) & \\
\hline $0 \cdot 00$ & $3 \cdot 50$ & A & 95 & 0 & 5 \\
\hline 0.99 & $4 \cdot 00$ & A & 95 & 0 & 5 \\
\hline $1 \cdot 00$ & $4 \cdot 00$ & A & 0 & 95 & 5 \\
\hline $1 \cdot 80$ & $0 \cdot 35$ & A & 0 & 95 & 5 \\
\hline $2 \cdot 00$ & $0 \cdot 35$ & $\mathrm{~B}$ & 0 & 95 & 5 \\
\hline $2 \cdot 50$ & $0 \cdot 35$ & $\mathrm{~B}$ & 0 & 95 & 5 \\
\hline $8 \cdot 00$ & $0 \cdot 35$ & $\mathrm{~B}$ & 0 & 20 & 80 \\
\hline $9 \cdot 60$ & $0 \cdot 35$ & $\mathrm{~B}$ & 0 & 20 & 80 \\
\hline $9 \cdot 61$ & $0 \cdot 35$ & $\mathrm{~B}$ & 0 & 1 & 99 \\
\hline $9 \cdot 63$ & $0 \cdot 80$ & B & 0 & 1 & 99 \\
\hline $11 \cdot 00$ & $0 \cdot 80$ & A & 0 & 1 & 99 \\
\hline $11 \cdot 02$ & $5 \cdot 00$ & A & 0 & 1 & 99 \\
\hline $11 \cdot 03$ & $5 \cdot 00$ & A & 1 & 0 & 99 \\
\hline $12 \cdot 01$ & $5 \cdot 00$ & A & 95 & 0 & 5 \\
\hline $12 \cdot 04$ & $4 \cdot 00$ & A & 95 & 0 & 5 \\
\hline $12 \cdot 54$ & $4 \cdot 00$ & A & 95 & 0 & 5 \\
\hline
\end{tabular}

Valve position A, sample extraction or washing on the SPE column; valve position B, back-flush onto the analytical column and chromatographic separation; mobile phase A-1, 1.0 vol\% formic acid; mobile phase A-2, 0.05 vol\% acetic acid; mobile phase B, methanol; the pump C delivered 0.05 vol\% acetic $\mathrm{acid} / \mathrm{methanol}(95: 5, \mathrm{v} / \mathrm{v})$ at $0 \cdot 35 \mathrm{ml} / \mathrm{min}$ to equilibrate the analytical column.

Chemical synthesis of $\left[{ }^{13} \mathrm{C}_{9}\right] \mathrm{T}_{4}$

$\left[{ }^{13} \mathrm{C}_{9}\right] \mathrm{T}_{4}$ was synthesized chemically from $\left[{ }^{13} \mathrm{C}_{9}\right]$ tyrosine using a modification of Salamonczyk's method (Salamonczyk et al. 1997; Fig. 2). The diiodo derivative of 1-oxaspiro $[2,5]$ bicycloocta-4,7-dien-6-one reacted readily with $\left[{ }^{13} \mathrm{C}_{9}\right] 3,5$-diiodo-L-tyrosine. In turn, the diiodo derivative of 1-oxaspiro[2,5]bicycloocta-4,7-dien-6-one was prepared by sodium bismuthate oxidation of diiodinated $p$-hydroxybenzyl alcohol derivative.

\section{Animals}

Seven-week-old male Sprague-Dawley rats were obtained from Charles River Laboratories Japan (Kanagawa, Japan). Animals were fed a commercial diet (AIN-93G, Oriental Yeast Co., Tokyo, Japan) and distilled water ad libitum. The cages were located in a light (0800-2000 h lights on), temperature $\left(23 \pm 5{ }^{\circ} \mathrm{C}\right)$ and humidity $(60 \pm 20 \%)$ controlled room.

The rats were allowed to acclimatize for 1 week before starting experiments.

All experimental procedures were approved by the Animal Research Committee of ASKA Pharmaceutical Co., in accordance with the Basic Guidelines for Proper Conduct of Animal Testing and Related Activities in the Research Institutions under the Jurisdiction of the Ministry of Health, Labour and Welfare of Japan.

\section{Thyroidectomy}

Rats were anesthetized with Isoflurane (Escain; Mylan, Pittsburgh, PA, USA). Thyroid glands were resected from the tracheal tube. After surgery, serum TSH rapidly increased and then achieved a steady state $(\sim 13 \cdot 4 \pm 3 \cdot 6 \mathrm{ng} / \mathrm{ml})$ after 7 days. Complete resection of the thyroid in the Tx rats

Table 2 Precision and accuracy of the intra-day assay. Data are expressed as the mean values \pm s.D. $(n=5)$. Figures in parentheses are expressed as coefficient of variance $(\%)$

\begin{tabular}{|c|c|c|c|c|}
\hline \multicolumn{5}{|c|}{$\%$ Accuracy $($ mean \pm s.D. $)$} \\
\hline & $\mathrm{T}_{4}$ & $\mathrm{~T}_{3}$ & $\mathrm{rT}_{3}$ & {$\left[{ }^{13} \mathrm{C}_{9}\right] \mathrm{T}_{4}$} \\
\hline \multicolumn{5}{|c|}{ Concentration (ng/ml) } \\
\hline $0 \cdot 1$ & $103 \cdot 0 \pm 4 \cdot 0(3 \cdot 9)$ & $95 \cdot 0 \pm 4 \cdot 0(4 \cdot 2)$ & $96 \cdot 0 \pm 2 \cdot 0(2 \cdot 1)$ & $101 \cdot 0 \pm 6 \cdot 0(5 \cdot 9)$ \\
\hline $0 \cdot 2$ & $105 \cdot 5 \pm 5 \cdot 5(5 \cdot 2)$ & $94 \cdot 0 \pm 5 \cdot 5(5 \cdot 9)$ & $93 \cdot 0 \pm 4 \cdot 5(4 \cdot 8)$ & $104 \cdot 0 \pm 4 \cdot 5(4 \cdot 3)$ \\
\hline 4 & $104 \cdot 4 \pm 2 \cdot 0(1 \cdot 9)$ & $99 \cdot 4 \pm 2 \cdot 8(2 \cdot 8)$ & $98 \cdot 0 \pm 2 \cdot 6(2 \cdot 7)$ & $104 \cdot 2 \pm 1 \cdot 9(1 \cdot 8)$ \\
\hline 80 & $97 \cdot 6 \pm 2 \cdot 0(2 \cdot 1)$ & $95 \cdot 1 \pm 2 \cdot 1(2 \cdot 2)$ & $97 \cdot 6 \pm 1 \cdot 4(1 \cdot 4)$ & $98 \cdot 2 \pm 1 \cdot 3(1 \cdot 4)$ \\
\hline
\end{tabular}

\footnotetext{
$T_{4}$, thyroxine; $T_{3}$, triiodothyronine; $r T_{3}$, reverse-triiodothyronine.
} 

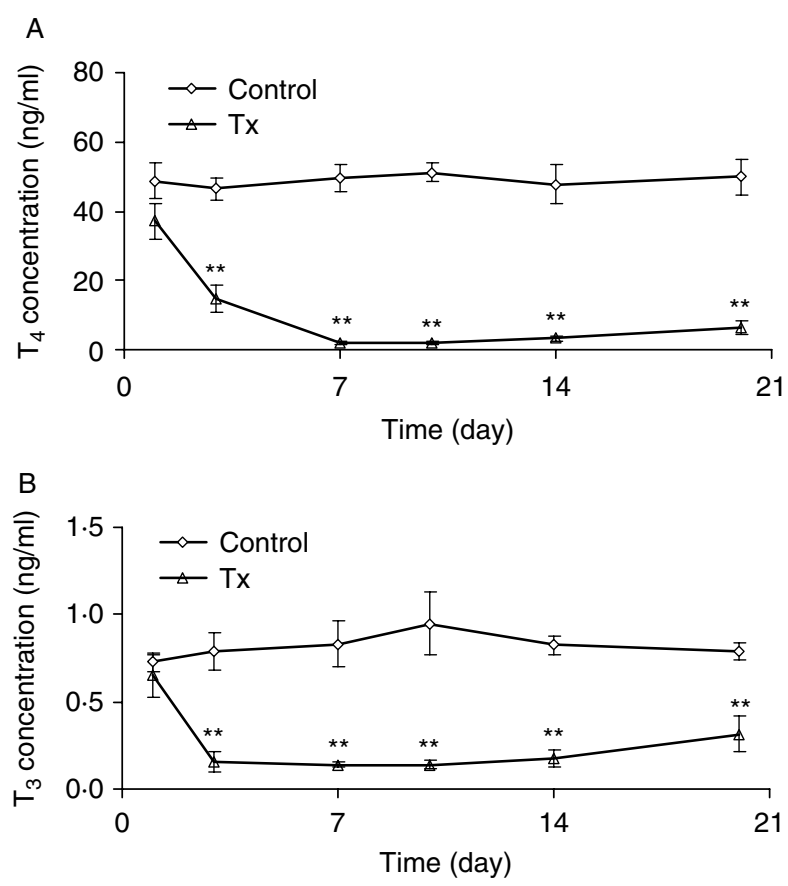

Figure 3 Changes of serum thyroid hormones concentration in control and $T x$ rats $(A) T_{4}$ and (B) $T_{3}$. Tx, thyroidectomy; $T_{4}$, thyroxine; $T_{3}$, triiodothyronine. All data represent the mean \pm S.D. of five animals. ${ }^{* *} P<0 \cdot 01$.

was confirmed at the end of the experiment by macroscopic observation at necropsy. In addition, serial sections from tracheal tubes (area of thyroid glands in $\mathrm{Tx}$ rats) were reviewed by a pathologist and hypertrophy or hyperplasia of follicular epithelial cells were not observed.

\section{Experiment 1}

Ten rats were divided into two groups $(n=5)$, the $\mathrm{Tx}$ and control groups. Serum samples were collected for 3 weeks. In control rats, serum TSH was maintained at $\sim 2 \cdot 2 \mathrm{ng} / \mathrm{ml}$ over the experimental period. All samples were obtained between 0900 and $1100 \mathrm{~h}$ to minimize fluctuations in thyroid hormones (Jeremiah et al. 1990).

\section{Experiment 2}

Five Tx rats were allowed 4 weeks to achieve steady-state plasma thyroid hormone concentrations after $\mathrm{Tx} .\left[{ }^{13} \mathrm{C}_{9}\right] \mathrm{T}_{4}$ was administered intravenously to $\mathrm{Tx}$ and control rats at a dose of $1.5 \mu \mathrm{g} / 500 \mu \mathrm{l} / \mathrm{kg} \quad(n=5$; Nguyen et al. 1993). Serum samples were obtained $5 \mathrm{~min}$ after $\left[{ }^{13} \mathrm{C}_{9}\right] \mathrm{T}_{4}$ administration, then at every $24 \mathrm{~h}$ for 2 weeks, and every $48 \mathrm{~h}$ for an additional week. All samples were kept frozen at $-20{ }^{\circ} \mathrm{C}$ until analysis.

\section{Online SPE LC-MS/MS}

The HPLC system (Shimadzu, Kyoto, Japan) consisted of a SCL-10Avp system controller, three LC-20AD pumps connected to an FCV-11AL reservoir selection valve, an SIL-HTc autosampler, and a CTO-20A column oven equipped with an FCV-12AH six-port switching valve for online extraction. The SPE column was a Shim pack MAYIODS, $2 \cdot 0 \mathrm{~mm}$ I.D. $\times 10 \mathrm{~mm}, 50 \mu \mathrm{m}$ (Shimadzu) maintained at $45^{\circ} \mathrm{C}$. The analytical column was a Synergi Polar-RP 80A, $2.0 \mathrm{~mm}$ I.D. $\times 50 \mathrm{~mm}, 4 \mu \mathrm{m}$ (Phenomenex, Utrecht, The Netherlands) maintained at $45^{\circ} \mathrm{C}$. The mobile phases were $1 \cdot 0$ $\mathrm{vol} \%$ formic acid (A-1), $0 \cdot 05 \mathrm{vol} \%$ acetic acid (A-2), methanol (B), and 0.05 vol\% acetic acid/methanol (95:5, v/v), respectively. The LC conditions are listed in Table 1. An API5000 triple-quadrupole mass spectrometer (AB SCIEX, Foster City, CA, USA) equipped with a TurboIonSpray source was operated in the positive ion multiple reaction monitoring (MRM) mode to perform the analysis. The transitions to monitor were selected for each compound: $\mathrm{m} / \mathrm{z} 777 \cdot 70$ $>731.50$ for $\left[{ }^{13} \mathrm{C}_{0}\right] \mathrm{T}_{4}, m / z 651.77>605.90$ for $\left[{ }^{13} \mathrm{C}_{0}\right] \mathrm{T}_{3}$, $m / z 651 \cdot 77>507 \cdot 73$ for $\left[{ }^{13} \mathrm{C}_{0}\right] \mathrm{rT}_{3}, m / z 786 \cdot 71>739 \cdot 90$ for $\left[{ }^{13} \mathrm{C}_{9}\right] \mathrm{T}_{4}$, and $m / z 782 \cdot 75>735 \cdot 90$ for $\left[{ }^{2} \mathrm{H}_{5}\right] \mathrm{T}_{4}$.

\section{Sample preparation}

A $20 \mu \mathrm{l}$ aliquot of rat serum was mixed with $60 \mu \mathrm{l}$ of internal standard solution $\left(2 \mathrm{ng} / \mathrm{ml}\right.$ of $\left.\left[{ }^{2} \mathrm{H}_{5}\right] \mathrm{T}_{4}\right)$. After vortex mixing, the mixture was centrifuged $\left(16000 \mathrm{~g}\right.$ for $5 \mathrm{~min}$ at $\left.10^{\circ} \mathrm{C}\right)$. Then, $40 \mu \mathrm{l}$ of $0 \cdot 1 \mathrm{vol} \%$ formic acid was added to the mixture and vortex mixed. After centrifugation $(16000 \boldsymbol{g}$ for $5 \mathrm{~min}$ at $\left.10^{\circ} \mathrm{C}\right), 80 \mu \mathrm{l}$ of the supernatant was injected into the LC-MS/MS system. Ten calibration standards ranging from
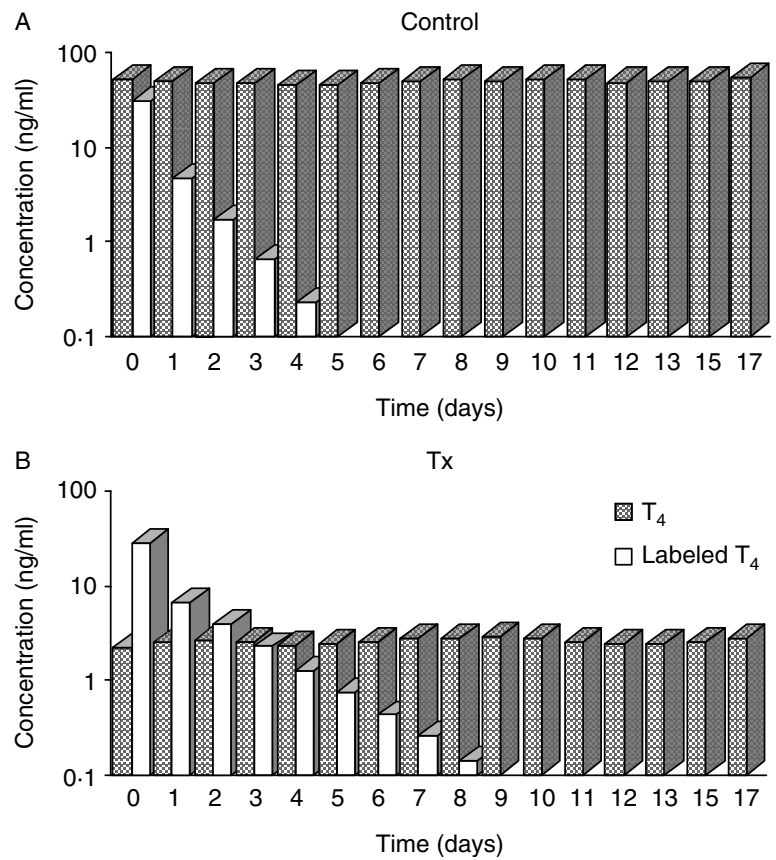

Figure 4 Serum concentrations of $\mathrm{T}_{4}$ and $\left[{ }^{13} \mathrm{C}_{9}\right] \mathrm{T}_{4}$ after an i.v. administration of $\left[{ }^{13} \mathrm{C}_{9}\right] \mathrm{T}_{4}$ to control $(\mathrm{A})$ and $\mathrm{Tx}(\mathrm{B})$ rats. $\mathrm{Tx}$, thyroidectomy; $\mathrm{T}_{4}$, thyroxine. 
Table 3 Supply rates and turnover of serum thyroxine $\left(T_{4}\right)$ in control and Tx rats. Data are expressed as the mean values \pm s.D. $(n=5)$

\begin{tabular}{|c|c|c|c|c|}
\hline \multirow[b]{2}{*}{ Group } & kel $\left(\right.$ day $\left.^{-1}\right)$ & $\boldsymbol{t}_{\mathbf{1} / \mathbf{2}}$ (day) & $\mathbf{V d}(\mathrm{ml})$ & SR (ng/day) \\
\hline & & & & \\
\hline $\begin{array}{l}\text { Control } \\
\text { Tx }\end{array}$ & $1 \cdot 19 \pm 0 \cdot 10$ & $0 \cdot 59 \pm 0 \cdot 05$ & $29 \cdot 8 \pm 4 \cdot 8$ & $\begin{array}{c}1723 \cdot 4 \pm 87 \cdot 7 \\
39 \cdot 9+5 \cdot 9\end{array}$ \\
\hline $\mathrm{Tx}$ & $0 \cdot 60 \pm 0 \cdot 02$ & $1 \cdot 16 \pm 0 \cdot 05$ & $26 \cdot 4 \pm 3 \cdot 8$ & $39 \cdot 9 \pm 5 \cdot 9$ \\
\hline
\end{tabular}

kel, turnover rate; $t_{1 / 2}$, half-life; $V d$, distribution volume; SR, supply rate; $\mathrm{Tx}$, thyroidectomy.

$0 \cdot 1$ to $100 \mathrm{ng} / \mathrm{ml}$ were prepared from charcoal-stripped rat serum. Similarly, four quality control samples were prepared with concentrations of $0 \cdot 1,0 \cdot 2,4$ and $80 \mathrm{ng} / \mathrm{ml}$. These levels were chosen to demonstrate the precision and accuracy of the method at the lower limit of quantitation (LLOQ) as well as at low, medium and high concentrations on the calibration curve.

\section{Data analysis}

The turnover rate (kel) was determined by plotting serum concentration of $\left[{ }^{13} \mathrm{C}_{9}\right] \mathrm{T}_{4}$ against time in a semilog plot,

$C=C_{0} \times \mathrm{e}^{-\mathrm{kel} \times t}$,

where $C$, serum concentration of $\left[{ }^{13} \mathrm{C}_{9}\right] \mathrm{T}_{4}$ at time $(t) ; C_{0}$, serum concentration of $\left[{ }^{13} \mathrm{C}_{9}\right] \mathrm{T}_{4}$ at time zero; $t$, time (day) and kel, turnover rate. The half-life $\left(t_{1 / 2}\right)$ of $\left[{ }^{13} \mathrm{C}_{9}\right] \mathrm{T}_{4}$ was calculated as $t_{1 / 2}=0 \cdot 693 / \mathrm{kel}$ (Kasuya et al. 2005).

The supply rate (SR) of $\mathrm{T}_{4}$ was calculated as follows:

$\mathrm{SR}=\mathrm{Css} \times \mathrm{Vd} \times \mathrm{kel}$,

where Css, steady state serum $\mathrm{T}_{4}$ concentration; $\mathrm{Vd}$, volume of distribution and $\mathrm{kel}$, turnover rate. $\mathrm{Vd}$ was calculated by the equation

$\mathrm{Vd}=\frac{X_{0}}{C_{0}}$

where $X_{0}$, dose of $\left[{ }^{13} \mathrm{C}_{9}\right] \mathrm{T}_{4}$ administered and $C_{0}$, serum concentration of $\left[{ }^{13} \mathrm{C}_{9}\right] \mathrm{T}_{4}$ at time zero.

\section{Statistical analysis}

The data are expressed as the mean \pm s.D. Statistical significance was calculated by unpaired Student's $t$-test. A $P$ value $<0 \cdot 01$ was considered significant.

\section{Results}

Online SPE LC-MS/MS

For $\mathrm{T}_{4}, \mathrm{~T}_{3}, \mathrm{rT}_{3}$ and $\left[{ }^{13} \mathrm{C}_{9}\right] \mathrm{T}_{4}$, intra-day precision and accuracy were evaluated by analysis of the $0 \cdot 1,0 \cdot 2,4$ and $80 \mathrm{ng} / \mathrm{ml}$ quality control samples. The results are summarized in Table 2. Overall, the intra-day precision was $<5.9 \%$ for each analyte at each quality control level, and the accuracy was between $93 \cdot 0$ and $105 \cdot 5 \%$. Therefore, the LLOQ of each analyte was established at $0 \cdot 1 \mathrm{ng} / \mathrm{ml}$.

These methods represent a specific and reliable technique for measurement of endogenous and stable isotopically labeled thyroid hormones in serum with a high degree of precision and accuracy.

\section{Serum concentrations of endogenous thyroid hormones}

After $\mathrm{Tx}_{\mathrm{x}}, \mathrm{T}_{4}$ and $\mathrm{T}_{3}$ levels decreased rapidly and achieved a steady state 7 days after treatment (Fig. 3). The steady-state $\mathrm{T}_{4}$ and $\mathrm{T}_{3}$ concentrations were $\sim 2$ and $0.1 \mathrm{ng} / \mathrm{ml}$, respectively. The $\mathrm{rT}_{3}$ concentration also rapidly decreased in Tx rats, dropping a level lower than the quantification limit $(0 \cdot 1 \mathrm{ng} / \mathrm{ml})$. In control rats, $\mathrm{T}_{4}, \mathrm{~T}_{3}$, and $\mathrm{rT}_{3}$ concentrations were maintained at $\sim 50,0.82$, and $0.76 \mathrm{ng} / \mathrm{ml}$, respectively, throughout the experimental period.

\section{Supply and turnover rates}

After a single i.v. administration of $1.5 \mu \mathrm{g} / \mathrm{kg}\left[{ }^{13} \mathrm{C}_{9}\right] \mathrm{T}_{4}$ to $\mathrm{Tx}$ and control rats, $\left[{ }^{13} \mathrm{C}_{0}\right] \mathrm{T}_{4}$ level was maintained at $\sim 2.6$ and $50 \mathrm{ng} / \mathrm{ml}$, respectively, throughout the experimental period (Fig. 4). In contrast, $\left[{ }^{13} \mathrm{C}_{9}\right] \mathrm{T}_{4}$ levels in both $\mathrm{Tx}$ and control rats rapidly decreased after administration of $\left[{ }^{13} \mathrm{C}_{9}\right] \mathrm{T}_{4}$, and were below the threshold for quantification by 9 days after treatment.

The turnover rate of serum $\left[{ }^{13} \mathrm{C}_{9}\right] \mathrm{T}_{4}$ in Tx rats was $0 \cdot 60 \pm 0 \cdot 02$ day $^{-1}$, approximately twofold slower than in controls $(1 \cdot 19$ $\pm 0 \cdot 10$ day $^{-1}$ ), and the $t_{1 / 2}$ was $\sim 1 \cdot 2$ days (Table 3 and Fig. 5).

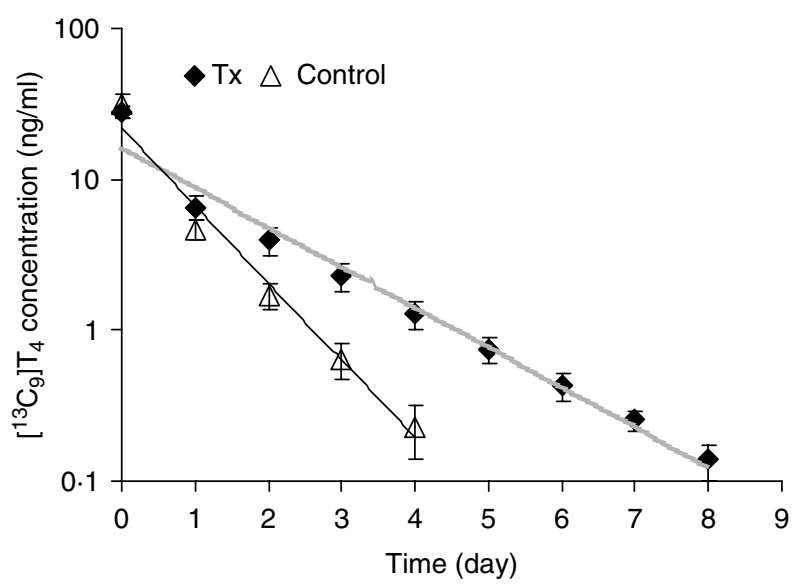

Figure 5 Turnover of serum $\mathrm{T}_{4}$ in control and $\mathrm{Tx}$ rats. $\mathrm{Tx}$, thyroidectomy; $\mathrm{T}_{4}$, thyroxine. 


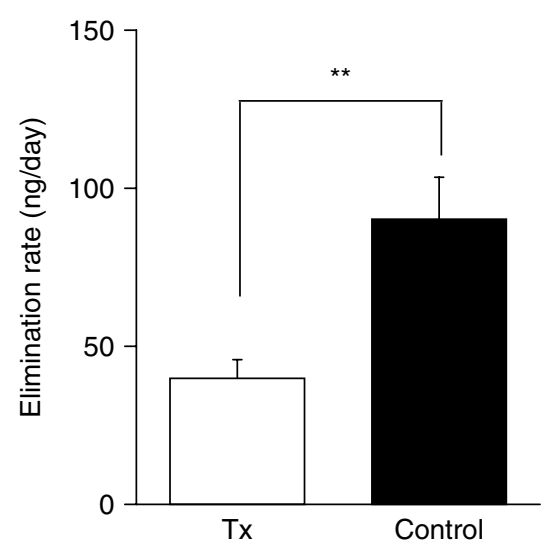

Figure 6 Suppression degree of elimination of serum $T_{4}$ in $T x$ rats. $\mathrm{Tx}$, thyroidectomy; $\mathrm{T}_{4}$, thyroxine. All data represent the mean \pm s.D. of five animals. ${ }^{* *} P<0 \cdot 01$.

The $\mathrm{T}_{4} \mathrm{SR}$ was $39 \cdot 9 \pm 5 \cdot 9 \mathrm{ng} / \mathrm{day}(2 \cdot 3 \%$ of that in control rats). The $\mathrm{T}_{4}$ elimination rate in controls (ERcnt), which was calculated using the kinetics parameters of control rats, was $\sim 2 \cdot 3$-fold faster than ERtx (Fig. 6 and Table 4).

\section{Discussion}

Concentrations of thyroid hormones in the plasma are strictly controlled by TSH, which is subject to negative feedback regulation by thyroid hormones. The major form of thyroid hormone secreted from the thyroid gland is $T_{4}$. In hypothyroidism, $\mathrm{T}_{4}$ is orally administered to maintain plasma thyroid hormones at a normal level. Although thyroid hormone levels are typically utilized to diagnose thyroid disease, thyroid hormone kinetics may also provide valuable information about the causes of thyroid hormone disorders.

To investigate the turnover rate of $T_{4}$ and changes in $T_{4}$ metabolism resulting from hypothyroidism, we synthesized a stable isotope-labeled compound and established an online SPE LC-MS/MS method. Conventional HPLC sample preparation is still labor-intensive and time-consuming, and requires many steps. Protein precipitation (PPT) is considered to be the fastest and simplest approach for extraction of hydrophilic and hydrophobic compounds. However, the extraction ratio, reproducibility, and selectivity of PPT are

Table 4 Suppression degree of elimination of serum thyroxine $\left(T_{4}\right)$ in Tx rats. Data are expressed as the mean values \pm s.D. $(n=5)$

ER (ng/day)

\begin{tabular}{llll}
\hline ERtx & ERcnt & $\frac{\mathbf{S} \text { (ng/day) }}{90 \cdot 2 \pm 13 \cdot 3}$ & $50 \cdot 3$ \\
\hline $39 \cdot 9 \pm 5 \cdot 9$ & \\
\hline
\end{tabular}

Tx, thyroidectomy; ER, elimination rate; ER, supply rate (SR) (in steady state); ERtx, SR for Tx rats. ERcnt $=\mathrm{Css} \times \mathrm{Vd} \times \mathrm{kel}$; where Css is $2.6 \mathrm{ng} / \mathrm{ml}$ for Tx rats, kel and $\mathrm{Vd}$ are each value for control rats. S, suppression degree for elimination of $\mathrm{T}_{4}, \mathrm{~S}=\mathrm{ERcnt}-\mathrm{ERtx}$. not sufficient to determine the concentrations of each analyte. Thus, we developed an online SPE assay using automated sample preparation instead of additional manual sample cleanup. The Shim Pak MAYI-ODS column was chosen for this assay because it can accommodate a large injection volume of PPT sample. Chromatographic focusing in the gradient elution produced very narrow peaks despite the large injection volume of $80 \mu \mathrm{l}$. Completely resolved peaks were obtained for $\mathrm{T}_{4}, \mathrm{~T}_{3}, \mathrm{rT}_{3}$ and $\left[{ }^{13} \mathrm{C}_{9}\right] \mathrm{T}_{4}$. Thorough cleanup by online SPE with high-efficiency LC separation and specific MRM detection conferred high selectivity. We used a novel combination of stable isotope-labeled tracer and online SPE LC-MS/MS to study thyroid hormone supply and turnover rates in Tx rats. Serum thyroid hormones $\left(T_{4}, T_{3}\right.$ and $\left.r T_{3}\right)$ decreased as a result of surgical $\mathrm{Tx}$, but were not completely abolished. At the steady state, hormone SRs are assumed to be in equilibrium with the elimination rates. Thus, we are able to estimate the elimination rate of labeled $\mathrm{T}_{4}$. In Tx rats, although endogenous $T_{4}, T_{3}$ and $\mathrm{rT}_{3}$ maintained at a constant level throughout the experimental period, the $\left[{ }^{13} \mathrm{C}_{9}\right] \mathrm{T}_{4}$ level declined with a half-life of about 1.2 days. These findings indicate that serum $T_{4}$ in $T x$ rats is maintained at a constant low level due to supply of $\mathrm{T}_{4}$ in extra-thyroidal tissues (e.g. secretion of extra-thyroidal storage, enhancement of enterohepatic recirculation and production in extra-thyroidal tissues) (SR: $39.9 \pm 5.9 \mathrm{ng} /$ day). A few previous reports in the literature have also suggested an unknown extrathyroidal source of thyroid hormone (Evans et al. 1966, Taurog \& Evans 1967, Obregon et al. 1981). In recent years, Meischl et al. (2008) reported that cardiomyocytes can produce thyroid hormone under specific experimental conditions. More recently, expression of transporters that act through thyroid hormone secretion (Visser et al. 2008, Cosmo et al. 2010) and $\mathrm{I}^{-}$intake (de Carvalho \& Quick 2011) have been reported in extrathyroidal organs. However, to the best of our knowledge, these studies have never been followed up to quantitatively elucidate the extrathyroidal sources of $\mathrm{T}_{4}$. Moreover, in $\mathrm{Tx}$ rats, the turnover rate of $\mathrm{T}_{4}$ was approximately twofold slower than in controls. This suggests that disappearance of serum $T_{4}$ is suppressed by $\mathrm{Tx}$, and the magnitude of the suppression was estimated to be $50 \cdot 3 \mathrm{ng} /$ day.

Tx may upregulate deiodination from $T_{4}$ to $T_{3}$ to mitigate hypothyroidism. Conversely, $\mathrm{T}_{4}$ glucuronidation and sulfation may be inhibited by $\mathrm{Tx}$. Changes in urinary excretion of $\mathrm{T}_{4}$ and deiodination of $\mathrm{T}_{4}$ to $\mathrm{rT}_{3}$ following $\mathrm{Tx}$ warrant further investigation. In addition to these changes in $\mathrm{T}_{4}$ metabolism, Vranckx et al. (1994) reported that Tx induces expression of $\mathrm{T}_{4}$-binding globulin (TBG), and suggested that regulation of TBG may thus be important for thyroid hormone homeostasis. Further study is required to completely determine the mechanisms of thyroid hormone homeostasis after Tx.

In conclusion, we have synthesized stable isotope-labeled $\mathrm{T}_{4}$ and have established a reliable and simple online SPE LCMS/MS method. We have also characterized thyroid hormone kinetics in Tx rats using a stable isotope tracer. In Tx rats, serum $\mathrm{T}_{4}$ was maintained at a constant low level due to thyroid 
hormone supply from extra-thyroidal tissues and decreased degradation of $\mathrm{T}_{4}$. The powerful online SPE LC-MS/MS tool can be used to investigate thyroid hormones kinetics and metabolism, and thus has the potential to be used as a diagnostic tool and to investigate the pathogenesis of thyroid disease. Our methods can be applied to future kinetic and metabolic studies of $\mathrm{T}_{4}$ in the hyperthyroid and hypothyroid states in humans.

\section{Declaration of interest}

The authors declare that there is no conflict of interest that could be perceived as prejudicing the impartiality of the research reported.

\section{Funding}

This research did not receive any specific grant from any funding agency in the public, commercial or not-for-profit sector.

\section{Acknowledgements}

We thank Dr Masanori Murakoshi for critically reviewing the manuscript and for histo-pathological examinations of tracheal tube.

\section{References}

Bianco AC, Salvatore D, Gereben B, Berry MJ \& Larsen PR 2002 Biochemistry, cellular and molecular biology, and physiological roles of the iodothyronine selenodeiodinases. Endocrine Reviews 23 38-89. (doi:10. 1210/er.23.1.38)

Blaak EE, Van Aggel-Leijssen DP, Wagenmackers AJ, Saris WH \& Van Baak MA 2000 Impaired oxidation of plasma-derived fatty acids in type 2 diabetic subjects during moderate-intensity exercise. Diabetes 49 2102-2107. (doi:10.2337/diabetes.49.12.2102)

de Carvalho FD \& Quick M 2011 Surprising substrate versatility in SLC5A6: $\mathrm{Na}^{+}$-coupled $\mathrm{I}^{-}$transport by the human $\mathrm{Na}^{+} /$multivitamin transporter (hSMVT). Journal of Biological Chemistry 286 131-137. (doi:10.1074/jbc. M110.167197)

Cosmo CD, Liao XH, Dumitrescu AM, Philp NJ, Weiss RE \& Refetoff S 2010 Mice deficient in MCT8 reveal a mechanism regulating thyroid hormone secretion. Journal of Clinical Investigation 120 3377-3388. (doi:10. 1172/JCI42113)

Evans ES, Taurog A, Koneff AA, Potter GD, Chaikoff IL \& Simpson ME 1960 Growth response of thyroidectomized rats to high levels of iodide. Endocrinology 67 619-634. (doi:10.1210/endo-67-5-619)

Evans ES, Schooley RA, Evans AB, Jenkins CA \& Taurog A 1966 Biological evidence for extrathyroidal thyroxine formation. Endocrinology 78 983-1001. (doi:10.1210/endo-78-5-983)

Gereben B, Zeold A, Dentice M, Salvatore D \& Bianco AC 2008 Activation and inactivation of thyroid hormone by deiodinases: local action with general consequences. Cellular and Molecular Life Sciences 65 570-590. (doi:10.1007/s00018-007-7396-0)

Hankard RG, Haymond MW \& Darnaum D 2000 Role of glucose in the regulation of glutamine metabolism in health and in type 1 insulindependent diabetes. American Journal of Physiology. Endocrinology and Metabolism 279 E608-E613.

Isojarvi JI, Pakarinen AJ \& Myllyla VV 1992 Thyroid function with antiepileptic drugs. Epilepsia 33 142-148. (doi:10.1111/j.1528-1157.1992.tb02297.x)

Jeremiah TH, Cynthia S \& Helen AB 1990 Long-term food restriction depresses serum thyroid hormone concentrations in the rat. Mechanisms of Ageing and Development 53 9-16. (doi:10.1016/0047-6374(90)90030-J)
Kasuya Y, Yokokawa A, Hamura K, Shibasaki H \& Furuta T 2005 Validation of the plasma half-life of 11alpha-deuterium cortisol as a sensitive index for the analysis of human 11beta-HSD2 activity in vivo. Steroids 70 811-816. (doi:10.1016/j.steroids.2005.05.004)

Kiang TK, Ensom MH \& Chang TK 2005 UDP-glucuronosyltransferases and clinical drug-drug interactions. Pharmacology and Therapeutics 106 97-132. (doi:10.1016/j.pharmthera.2004.10.013)

Lin LC, Wu HY, Tseng VS, Chen LC, Chang YC \& Liao PC 2010 A statistical procedure to selectively detect metabolite signals in LC-MS data based on using variable isotope ratios. Journal of the American Society for Mass Spectrometry 21 232-241. (doi:10.1016/j.jasms.2009.10.002)

Meischl C, Buermans HP, Hazes T, Zuidwijk MJ, Musters RJ, Boer C, van Lingen A, Simonides WS, Blankenstein MA, Duppy C et al. 2008 H9c2 cardiomyoblasts produce thyroid hormone. American Journal of Physiology. Cell Physiology 294 1227-1233. (doi:10.1152/ajpcell.00328.2007)

Miners JO, McKinnon RA \& Mackenzie PI 2002 Genetic polymorphisms of UDP-glucuronosyltransferases and their functional significance. Toxicology 181-182 453-456. (doi:10.1016/S0300-483X(02)00449-3)

Nguyen TT, DiStefano JJ, Yamada H \& Yen YM 1993 Steady state organ distribution and metabolism of thyroxine and 3,5,3'-triiodothyronine in intestine, liver, kidneys, blood and residual carcass of the rat in vivo. Endocrinology 133 2973-2983. (doi:10.1210/en.133.6.2973)

Obregon MJ, Mallol J, Escobar del Rey F \& Morreale de Escobar G 1981 Presence of L-thyroxine and 3,5, $3^{\prime}$-triiodo-L-thyronine in tissues from thyroidectomized rats. Endocrinology 109 908-913. (doi:10.1210/endo-109-3-908)

Ohnhaus EE \& Studer H 1983 A link between liver microsomal enzyme activity and thyroid hormone metabolism in man. British Journal of Clinical Pharmacology 15 71-76.

Salamonczyk GM, Oza VB \& Sih CJ 1997 A concise synthesis of thyroxine $\left(\mathrm{T}_{4}\right)$ and 3,5,3'-triiodo-L-thyronine $\left(\mathrm{T}_{3}\right)$. Tetraheron Letters 38 6965-6968. (doi:10.1016/S0040-4039(97)01665-1)

Silva JE \& Matthews PS 1984a Production rates and turnover of triiodothyronine in rat-developing cerebral cortex and cerebellum. Responses to hypothyroidism. Journal of Clinical Investigation 74 1035-1049. (doi:10.1172/JCI111471)

Silva JE \& Matthews P $1984 b$ Thyroid hormone metabolism and the source of plasma triiodothyronine in 2-week-old rats: effects of thyroid status. Endocrinology 114 2394-2405. (doi:10.1210/endo-114-6-2394)

Silva JE, Gordon MB, Crantz FR, Leonard JL \& Larsen PR 1984 Qualitative and quantitative differences in the pathways of extrathyroidal triiodothyronine generation between euthyroid and hypothyroid rats. Journal of Clinical Investigation 73 898-907. (doi:10.1172/JCI111313)

Taurog A \& Evans ES 1967 Extrathyroidal thyroxine formation in completely thyroidectomized rats. Endocrinology 80 915-925. (doi:10.1210/ endo-80-5-915)

Visser TJ 1994 Sulfation and glucuronidation pathways of thyroid hormone metabolism. In Thyroid Hormone Metabolism: Molecular Biology and Alternate Pathways, pp 85-117. Eds SY Wu \& TJ Visser. Boca Raton, FL: CRC Press.

Visser WE, Friesema EC, Jansen J \& Visser TJ 2008 Thyroid hormone transport in and out of cells. Trends in Endocrinology and Metabolism 19 50-56. (doi:10.1016/j.tem.2007.11.003)

Vranckx R, Rouaze-Romet M, Savu L, Mechighel P, Maya M \& Nunez EA 1994 Regulation of rat thyroxine-binding globulin and transthyretin: studies in thyroectomized and hypophysectomized rats given triiodothyronine or/and growth hormone. Journal of Endocrinology 142 77-84. (doi:10.1677/joe.0.1420077)

Yamanaka H, Nakajima M, Katoh M \& Yokoi T 2007 Glucuronidation of thyroxine in human liver, jejunum, and kidney microsomes. Drug Metabolism and Disposition 35 1642-1648. (doi:10.1124/dmd.107.016097)

Received in final form 1 April 2011

Accepted 8 April 2011

Made available online as an Accepted Preprint 8 April 2011 